Egyptian Journal of Aquatic Biology \& Fisheries

Zoology Department, Faculty of Science,

Ain Shams University, Cairo, Egypt.

ISSN $1110-6131$

Vol. 23(4): 483 - 490 (2019)

www.ejabf.journals.ekb.eg

\title{
Molluscicidal effect of some red and green marine algae on Lymnaea natalensis
}

\author{
Abd El-Halim A. Saad ${ }^{1}$, Mohey A. Hassanain ${ }^{2}$, Eman M. Darwish ${ }^{3}$, \\ Eman H. Abdel-Rahman ${ }^{3}$, Setaita H. Sleem ${ }^{1}$ and Raafat M. Shaapan, ${ }^{2, *}$ \\ 1- Zoology Department, Faculty of Science, Ain Shams University, Cairo, Egypt \\ 2- Department of Zoonotic Diseases, National Research Center, Dokki, Giza, Egypt \\ $3-$ Department of Parasitology and Animal Diseases, Veterinary Research Division, National \\ Research Centre, Dokki, Giza, Egypt. \\ *Corresponding Author: rmshaapan2005@yahoo.com
}

\section{ARTICLE INFO}

Article History:

Received: Aug. 25, 2019

Accepted: Oct. 28, 2019

Online: Nov. 2019

\section{Keywords:}

Marine algae

Lymnaea natalensis

Molluscicide

Fasciola gigantica

bioactive metabolites

Ulva lactuca

Jania rubens

\section{ABSTRACT}

Marine algae are economically important aquatic photosynthetic organisms act as a source of highly bioactive metabolites that might be useful against predators and parasites. In the present study, aqueous and ethanol extracts of four algal species of marine algae; Pterocladia capillacaea ( $P$. capillacaea), Jania rubens (J. rubens), Ulva lactuca (U. lactuca), and Enteromorpha intestinalis (E. intestinalis) were tested for their lethal effect on Lymnaea natalensis (L. natalensis) snail, the intermediate host of the trematode parasite; Fasciola gigantica, $(F$. gigantica). Preliminary experiments were done to determine the molluscicidal toxicity of different concentrations of aqueous and ethanol algal extracts against the studied snail. Five concentrations of aqueous and ethanol extracts; 100, 200, 300, 400 and $500 \mathrm{ppm}$ for each algal species were used. LC $_{50}$ for each extract was calculated daily till the end of the experiment. It is clear from the results that molluscicidal effect of algal extracts is concentration dependent. The most potent extracts as proved by calculated $\mathrm{LC}_{50}$ are $P$. capillacaea and J. rubens aqueous extract (red algae); 111.3 and 127 ppm respectively and $U$. lactuca ethanolic extract (green algae) $121 \mathrm{ppm}$. The current study introduces marine algae of promising molluscicidal activity on L. natalensis snail. P. capillacaea and J. rubens aqueous extracts and $U$. lactuca ethanolic extract are the most potent and highly significant ones in the net reproductive rate and reduction. Further investigations for isolation of active principals of the algal potent extracts for evaluation as molluscicides and or anthelmintics are necessary required.

\section{INTRODUCTION}

Marine algae are economically important as a source of crude oil and as sources of food and number of pharmaceutical and industrial products for humans. An important role in medicine and rich in secondary metabolites and include several natural products (Iwamoto et al. 2001). During the last five decades, numerous novel compounds have been isolated from marine organisms and many of these substances have been demonstrated to possess interesting biological activities The phytochemical screening of the marine algae revealed the presence of saponins, alkaloids, glycosides, flavonoids, tannins, phenols, steroids, terpenoids, nitrogenous compounds and volatile 
constituents which are of great medicinal value and used in drugs (El Gamal, 2010). The intermediate host of worldwide zoonotic trematode parasite Fasciola gigantica (F. gigantica) in Egypt, Lymnaea natalensis (L. natalensis) snail, has received a great attention because of its role in transmission of fasciolosis in man and animals. The snail control is considered not only complementary but essential in breakage Fasciola life cycle (Shaapan et al. 2015).

Marine organisms as red, green and brown algae have shown to be one of the most promising sources of new bioactive compounds. (Blunt et al. 2013; Mayer et al. 2013). Algal metabolism concerns the biological and transport processes by which the algae take up nutrients and convert them into materials needed for growth, reproduction and defense of the organisms. It gives rise to a range of unique compounds, including secondary metabolites, some of which have toxicity to other organisms (Raven et al. 2012). The preliminary phytochemical screening of the algal species revealed the presence of steroids, phenolic groups, saponins, tannins, flavonoids, carbohydrates, carboxylic acid, coumarins and xantho-proteins in green algae, Ulva lactuca, (U. lactuca) (Jeeva et al. 2012). Analysis of volatile constituents led to identification of 27 components from $U$. lactuca. One of the major components is thymol which constituents $18.24 \%$ of volatiles (Elmanawy et al. 2005). It was found that the green algae (Ulva lactuca), and the two red algal, Jania rubens and Pterocladia capillacea (J. rubens and P. capillacea) extracts contained flavonoids and phenolics (Yacout et al. 2011). The presence of steroids, cardiac glycosides and saponins were detected in Enteromorpha intestinalis with absence of tannins, flavonoids and alkaloids (Rathish et al. 2009). The secondary metabolites of the collected red alga Pterocladia capillacea from the Mediterranean Coast of Egypt were isolated. Their chemical structures were elucidated and also diisooctyl phthalate, cholesterol, stigmasterol, linoleic acid and isodomoic acid were isolated from $P$. capillacea (Aboutabl et al. 2010). The presence of alkaloids in aqueous extract of $P$. capillacaea is previously proved by (El Kassas and Attia 2014). The byproducts of the blue-green alga, Spirulina platensis, has a lethal effect against adult Biomphalaria. alexandrina snails, reduced or stopped their oviposition, and has effect on hatchability of snail's eggs and viability of the free living larval stages of the parasite (miracidia and cercariae), hence minimize the snail populations available for the parasite transmission. Therefore, it may be a potential source of effective compounds for control of Schistosoma mansoni (Mostafa and Gawish, 2009).

A decrease of growth regardless age in juveniles and adults, and a reduction of fecundity in adults Lymnaea stagnalis snails were recorded after ingestion of toxic Planktothrix agardhii (Cyanobacteria, Phormidiaceae).The Survival and locomotion of the snails were not affected. Reduction of growth and fecundity continued to be observed even after feeding of non-toxic food for 3 weeks (Lance et al. 2007).

The objective of the current research is to assess the molluscicidal effect of some marine algae; red and green ones against Lymnaea natalensis snails for controlling fascioliases.

\section{MATERIALS AND METHODS}

The experiments were done in Parasitology and Animal Disease laboratory, National Research Center, Giza .Egypt.

\section{Snails}

Lymnaea natalensis snails were collected from Abou Rawash, Giza and kept in aquaria $(35 \times 25 \times 10 \mathrm{~cm})$ filled with $0.5 \mathrm{~L}$ dechlorinated tap water each aquarium and 
fed on fresh leaves of lettuce. The water was changed daily and dead snails were removed, live snails were maintained reared two weeks before use in experiments according to the methods described by Van der Steen, et al. (1968). A control group was prepared in dechlorinated water. Snails were exposed to the tested materials at room temperature $27{ }^{\circ} \mathrm{C}$ and the tested snails were examined daily to assess activity, physiological and mortality changes.

\section{Tested algae}

Four different species of marine algae; two species are belong to family Chlorophyceae (green algae); Ulva lactuca and Enteromorpha intestinalis and two species of family Rhodophyceae (red algae); Pterocladia capillacea and Jania rubens were used. The algal samples were collected from exposed rocky site near the western edge of Abou-Qir bay, Alexandria, Egypt about 100 meters from the sea shore and at about 1 meter depth. The selection of the four species of algae was based on previous studies (Awad., 2000; El Sayed et al. 2001 (Revise high light with the Ref. list??); Hutson et al. 2012). The tested algae were thoroughly washed by sea water to remove extraneous matters, then dried in shade and finely grounded. Aqueous and ethanol extracts of the four different species of marine algae were prepared according the procedure of Singaba et al. (2006). Identification of the algal species was carried out according to methods described by Chaumont (1993) and Barsanti and Gualtieri (2014) and was also checked by Dr. Manal El-Naggar, Professor of Microbiology and Head of Microbiology Department; National Institute of Oceanography and Fisheries, Alexandria, Egypt.

\section{Preliminary experiment for determination of molluscicidal toxicity}

The evaluation of the molluscicidal toxicity of the extracts was conducted according to the world health organization (WHO) guideline application (WHO, 1983). A stock solution of $1000 \mathrm{ppm}$ was prepared on the basis of w/v using dechlorinated water. A series of exploratory experiments were conducted using different concentrations to determine the toxicity range of the algal extracts against the tested snails. In the current experiment, five concentrations of aqueous and ethanol extract, each $(100,200,300,400$ and $500 \mathrm{ppm})$ for each algal species were used for snails (Miyasato et al. 2012). Ten snails were transferred to a glass aquarium containing $50 \mathrm{ml}$ dechlorinated tap water as control and three replicates each of ten snails were used for each mentioned algal concentration. For each treatment, the mortality percentages were calculated. This experiment was assayed for the algal extract activity on L. natalensis snails. Determination of snail fecundity was performed by collection of egg masses produced by snails. The aquaria were lined with plastic sheets for easy collection of egg masses and the numbers of eggs in each egg mass were counted by the use of light microscope. The total number of eggs laid by treated and control snails were recorded daily. The egg-laying capacity was expressed here in the form of the number of eggs/snails/day and this was determined by dividing the total number of laid eggs in any day by the total number of living snails of this day (Czech et al. 2001). In order to calculate the net reproductive rate of L. natalensis snails throughout their continuous exposure to different concentrations of experimental materials, the following parameters will be considered. Time of exposure in days, survival rate which is the living snails at any given day as a proportion from the original snails, fecundity which means the number of eggs/snails/day and multiplication of the previous two parameters give the product of each day. The summation of the reproductive product of the exposed snails throughout the experiment period gives the still survived snail (Ro). The reduction 
percentage (Red) was calculated according to (Osman et al. 2014) by using the following equation:

$$
\begin{aligned}
& \text { Control - treated } \\
& \text { Reduction in reproductive rate = --------------------------- X } 100
\end{aligned}
$$

Which means the dead destructive snails

\section{Determination of $\mathrm{LC}_{50}$ for different extracts}

The $\mathrm{LC}_{50}$ for each aqueous and ethanol algal extract was calculated daily till the end of the experiment according to method adopted by Dahms and Hellio (2009).

\section{RESULTS}

\section{Molluscicidal effect of the algal extracts on snail activates Lymnaea natalensis}

Treated snails with potent extract was showed lowest values of net reproductive rate (Ro) for survived snails were $0.56,0.66,0.88$ and 0.89 in $P$. capillacae, $U$. lactuca, J. rubens and E. intestinalis aqueous extracts, respectively with algal extract concentrations 300, 500, 500 and 500 ppm, respectively. The highest values of Ro were 3.63 and 4.01 in $U$. lactuca and E. intestinalis ethanol extracts, respectively with algal extract concentrations 400 and 500 ppm, respectively. At the same time, Ro values of $J$. rubens and $P$. capillacae ethanol extracts revealed 1.96 and 2.85, respectively with algal extract concentrations $500 \mathrm{ppm}$. The still survived snail Ro of control non-treated snail was 95.9. The time of snail exposure to different algal concentrations ranged between 3-7 days at 300 -500 ppm concentrations. The lowest time of exposure was 3 days for J. rubens, $U$. lactuca and E. intestinalis aqueous extracts. The highest time of exposure was 6, 6 and 7 days for P. capillacae, $U$. lactuca and E. intestinalis ethanol extracts, respectively. At the same time J. rubens ethanol extract had 4 days of exposure (Table 1).

Table 1: Effect of some red and green algae spp on L. natalensis snail activities (R0 \& Red) in relation to time of exposure

\begin{tabular}{ccccc}
\hline Algal Extract & $\begin{array}{c}\text { Snail activates } \\
\text { Concentration } \\
\text { ppm }\end{array}$ & $\begin{array}{c}\text { Time of exposure } \\
\text { (days) }\end{array}$ & Ro & Red \\
\hline $\boldsymbol{P}$. capillacea Aqueous & 300 & 5 & 0.56 & 98.5 \\
$\boldsymbol{P}$. capillacea Ethanol & 500 & 6 & 2.85 & 92.1 \\
$\boldsymbol{J}$. rubens Aqueous & 500 & 3 & 0.88 & $97 ; 7$ \\
$\boldsymbol{J}$ rubens Ethanol & 500 & 4 & 1.96 & 95.2 \\
$\boldsymbol{U}$. lactuca Aqueous & 500 & 3 & 0.66 & 98.3 \\
$\boldsymbol{U}$. lactuca Ethanol & 400 & 6 & 3.63 & 92.9 \\
$\boldsymbol{E}$. intestinalis Aqueous & 500 & 3 & 0.89 & 97.7 \\
$\boldsymbol{E}$. intestinalis Ethanol & 500 & 7 & 4.01 & 90.8 \\
Control & & 10 & 95.9 & 3.66 \\
\hline
\end{tabular}

Ro: the net reproductive rate of the still survived snails throughout the experimental period (still survived snails)

Red: reduction in reproductive rate (dead destructive snails)

\section{$\mathrm{LC}_{50}$ value of the algal extracts on Lymnaea natalensis snails}

The $\mathrm{LC}_{50}$ value of each aqueous and ethanolic extract corresponding to each tested alga are showed in table 2.The LC50 value clears and evaluates the molluscicidal effect of each alga against $L$. natalensis snails particularly through field application. The most potent is $P$. capillacea aqueous extract (111.295) followed by $U$. lactuca ethanolic extract (121.237). The lowest molluscicidal effects are $E$. 
intestinalis ethanolic extract (382.569) followed by U. lactuca and E. intestinalis aqueous extracts (371.365 \& 370.182, respectively) (Table 2).

Table 2: $\mathrm{LC}_{50}$ values of aqueous and ethanol extracts of the marine studied algae

\begin{tabular}{ccccc}
\hline \multirow{2}{*}{ Extract } & \multicolumn{4}{c}{ Marine algae } \\
\cline { 2 - 5 } & $\boldsymbol{P}$. capillacea & J. rubens & U. lactuca & E. intestinalis \\
\hline Aqueous & 111.295 & 127.128 & 371.365 & 370.182 \\
Ethanol & 180.221 & 150.303 & 121.273 & 382.569 \\
\hline
\end{tabular}

\section{DISCUSSION}

The use of molluscicides is regarded as an important strategy in the control of the snail hosts of fasciolosis (Mello-Silva et al. 2006). Unlike the synthetic drugs, the uses of molluscicides to control snails prevent reinfection of people after treatment (WHO, 2002). Therefore, the search for new molluscicides is still ongoing although there are little reports on molluscicidal natural products from marine organisms to control the population of intermediate host snails of fasciolosis (Miyasato et al. 2012).

In the present study, the crude ethanol and water extracts from four different algal species, P. capillacaea, J. rubens (Rhodophyta), U. lactuca and E. intestinalis (Chlorophyta), were screened for their biological activity against L. natalensis snails. It is obvious in the present study that aqueous extract of different experimental algae are more effective than ethanolic one. Also highest dilution, $500 \mathrm{ppm}$ was effective in all algal extracts except $P$. capillacaea aqueous one at $300 \mathrm{ppm}$. Moreover, this extract had the most prominent lowest $\mathrm{R}_{0}(0.56)$ and highest Red (98.5) and can play as an important molluscicide. The lowest molluscicidal effects are 3.63 and 4.01 in $U$. lactuca and E. intestinalis ethanolic extracts, respectively. The $\mathrm{LC}_{50}$ value was encouraged and revealed that most potent is $P$. capillacea aqueous extract (111.295) besides $U$. lactuca ethanolic extract (121.237). The lowest $\mathrm{LC}_{50}$ are E. intestinalis ethanolic extract (282.569) followed by $U$. lactuca and E. intestinalis aqueous extract (371.365 \& 370.182), respectively. These obtained result may be attributed to the presence of saponins, alkaloids and mineral salts that facilitate and accelerate the rate of penetration of algal byproducts through snail's membrane, hence increase their harmful effects and decrease snail fecundity in accordance to Tadros et al. (2008), who stated that low concentrations of saponins fractions increased mortality of $B$. alexandrina snails, miracidia, cercariae and adult worm of Schistosoma mansoni and decreased hatchability and egg production. Similarly, Mostafa and Gawish (2009), attributed this harmful effect to the content of the phenolic compounds, saponins, alkaloids and mineral salts. Also, embryo toxicity and reduced viability of eggs was observed due to expoure to theses algal byproducts (Oliveira-Filho et al. 2010). Moreover, survival and snail population were reduced in an infested region. The reduced fecundity of $L$. natalensis that observed in the current results after exposure to marine algae also agree with the results proved suppressed fecundity of snails treated with Cladophora glomerata algae (Ishac and Bishai, 1968). The authors stated that alga secrets substance (acrylic acid), which causes high mortality, low fecundity and low hatchability of affected snails. This explanation was also adopted by Bakry, (2009), who indicated that S. platensis secrets organic substances or metabolic products such as phycobiline, phenols, terponoids, steroids, polysaccharides and saponins.

Meanwhile, the ethanol and aqueous extracts of $J$. rubens had no molluscicidal activity against $B$. alexandrina (Soliman et al. 1994) which disagrees with the result 
of the current study since $P$. capillacea aqueous extract, $U$.lactuca ethanolic extract and $J$. rubens aqueous extracts had a potent molluscicidal activity on $L$. natalensis. This conflict is probably attributed to snail species where the difference is in susceptibility of the two snails to the lethal effect of the same extract could be attributed to the natural resistance of different snail's genera and that the molluscicides may vary in their toxicological effects according to the species of the snails' used (Bakry and Hamdi, 2007; Osman et al. 2014).

\section{CONCLUSIONS}

Collectively, the four tested marine algae showed variable molluscicidal and anthelminthic potentials against $L$. natalensis snails (intermediate host of $F$. gigantica). Aqueous extract of $P$. capillacaea showed the most potent molluscicidal effect while ethanol extract of $E$. intestinalis and $U$. lactuca showed the most lowest molluscicidal impact. The current promising results merit further investigations for isolation of active principals of the potent algal extracts and its experimental field application as molluscicides and or in vivo evaluation as anthelmintics.

\section{REFERENCES}

Aboutabl, A.E.; Abou-Zeid, A.H; Sleem, A.A. and El Rafi, H.M. (2010). Secondary metabolites and certain bioactivities of Pterocladia capillacea (S. Gmelin) Bornet and Dictyopteris membranacea (Stackhouse) Batters. Med Aro Plant Sci Biotechnol., 4: 41-48.

Awad, N.E. (2000). Biologically active steroid from the green alga Ulva lactuca. Phytotherapy Research: Int J Dev Pharmacolo Toxicolo Eval Nat Prod Deriv., 14: 641-643.

Bakry, F.A. and Hamdi, S.A.H. (2007). Molluscicidal activity of latex aqueous solution of Euphorbia acetonitril and Euphorbia granulate against the intermediate hosts of Schistosomiasis and Fascioliasis. Journal of Union Arab Biologist, 27: 101-126.

Bakry, F.A. (2009). Use of some plant extracts to control Biomphalaria alexandrina snails with emphasis on some biological effects. Pesticide biochemistry and physiology, 95: 159-165.

Barsanti, L. and Gualtieri, P. (2014). Algae: anatomy, biochemistry, and biotechnology. CRC press, Taylor. \& Francis Group, Boca Raton, FL, USA. ISBN-13: 978-1-4398-6733-4.

Blunt, J.W.; Copp, B.R.; Keyzers, R.A.; Munro, M.H. and Prinsep, M.R. (2013). Marine natural products. Natural product reports, 30: 237-323.

Chaumont, D. (1993). Biotechnology of algal biomass production: a review of systems for outdoor mass culture. J. Appl Phycol., 5: 593-604.

Czech, P.; Weber, K. and Dietrich, D. R. (2001). Effects of endocrine modulating substances on reproduction in the hermaphroditic snail Lymnaea stagnalis. Aquatic Toxicology, 53: 103-114.

Dahms, H.U. and Hellio, C. (2009). Laboratory bioassays for screening marine antifouling compounds. In Advances in marine antifouling coatings and technologies, pp: 275-307.

El Gamal, A.A. (2010). Biological importance of marine algae. Saudi Pharmaceutical Journal, 18: 1-25. 
El Kassas, H.Y. and Attia, A.A. (2014). Bactericidal application and cytotoxic activity of biosynthesized silver nanoparticles with an extract of the red seaweed Pterocladiella capillacea on the HepG2 cell line. Asian Pac J Cancer Prev., 15: 1299-1306

El Sayed, H.; Choudhary, M.I.; Kandil, S.H.; El Nemr, A.; Gulzar, T. and Shobier, A.H. (2011). Studies on the constituents of the green alga Ulva lactuca. Chemistry of Natural Compounds, 47: .335.

Elmanawy, I.M.; Hafez, S.S.; Yassin, M.; El-adel, H.M. and Eraqi, I.S. (2005). Phytochemical investigation and anti-microbial activity of Ulva lactuca. Egyp J. Phycol., 6: 28

Hutson, K.S.; Mata, L.; Paul, N.A. and De Nys, R. (2012). Seaweed extracts as a natural control against the monogenean ectoparasite, Neobenedenia sp., infecting farmed barramundi (Lates calcarifer). Int J parasitol, 42: 1135-1141.

Ishac, M.M. and Bishai, H.M. (1968). the possible role of the algae Cladophora glomerata on the biological control of Biomphalaria boissyi, the snail host of Schistosoma mansoni. Hydrobiologia, 32: 168-180.

Iwamoto, C.; Yamada, T.; Ito, Y.; Minoura, K. and Numata, A. (2001). Cytotoxic cytochalasans from a Penicillium species separated from a marine alga. Tetrahedron, 57: 2904-2997.

Jeeva, S.; Marimuthu, J.; Domettila, C.; Anantham, B. and Mahesh, M. (2012). Preliminary phytochemical studies on some selected seaweeds from Gulf of Mannar, India. Asian Pac. J. Trop. Biomed, 2: S30-S33.

Lance, E.; Paty, C.; Bormans, M.; Brient, L and Gérard, C. (2007). Interactions between cyanobacteria and gastropods. Aquatic Toxicology, 4: 389-396.

Mayer, A.; Rodríguez, A.D.; Taglialatela-Scafati, O. and Fusetani, N. (2013). Marine pharmacology in 2009-2011: Marine compounds with antibacterial, antidiabetic, antifungal, anti-inflammatory, antiprotozoal, antituberculosis, and antiviral activities; affecting the immune and nervous systems, and other miscellaneous mechanisms of action. Marine drugs, 11: 2510-2573.

Mello-Silva, C.C.; Vasconcellos, M.C.D.; Pinheiro, J. and Rodrigues, M.D.L.D.A. (2006). Physiological changes in Biomphalaria glabrata Say, 1818 (Pulmonata: Planorbidae) caused by sub-lethal concentrations of the latex of Euphorbia splendens var. hislopii NEB (Euphorbiaceae). Memórias do Instituto Oswaldo Cruz, 101: 3-8.

Miyasato, P.A.; Kawano, T.; Freitas, J.C.; Berlinck, R.G.D.S.; Nakano, E. and Tallarico, L.F. (2012). Molluscicidal activity of some marine substances against the snail Biomphalaria glabrata (Mollusca, Planorbidae). Parasitol Res., 110: 1873-1879.

Mostafa, S.S. and Gawish, F.A. (2009). towards to control Biomphalaria alexandrina snails and the free living larval stages of Schistosoma mansoni using the microalga Spirulina platensis. Austr J Bas. Appl Sci., 3: 4112-4119.

Oliveira-Filho, E.C.; Geraldino, B.R.; Coelho, D.R.; De-Carvalho, R.R. and Paumgartten, F.J. (2010). Comparative toxicity of Euphorbia milii latex and synthetic molluscicides to Biomphalaria glabrata embryos. Chemosphere, 81: 218-227.

Osman, G.Y., Mohamed, A.Z.; Sheir, K.S.; Hassab EL Nabi, S.E. and Allam, A.S. (2014). Molluscidal activity of Mirazid on Biomphalaria alexandrina snails: biological and molecular studies. Inter J. Adv. Res., 2: 977-989. 
Rathish, N.; Yogeshkumar, V. and Sumitra, C. (2009). Preliminary phytochemical analysis of some marine algae of western coast of Gujarat. Plant Archives, 9: 173-174.

Raven, J.A.; Giordano, M.; Beardall, J. and Maberly, S.C. (2012). Algal evolution in relation to atmospheric $\mathrm{CO} 2$ : carboxylases, carbon-concentrating mechanisms and carbon oxidation cycles. Phil. Trans. R. Soc. B, 367: 493-507.

Shaapan, R.M.; Toaleb, N.I. and Abdel-Rahman, E.H. (2015). Significance of a common $65 \mathrm{kDa}$ antigen in the experimental fasciolosis and toxoplasmosis $\mathrm{J}$ Par Dis. 39: 550-556.

Singaba, A.N.B.; Ahmed, A.H.; Sinkkonen, J.; Ovcharenko, V. and Pihlaja, K. (2006). Molluscicidal activity and new flavonoids from Egyptian Iris germanica L (var. alba) Zeitschrift für Naturforschung C, 61: 57-63.

Soliman, F.M.; El Tohamy, S.F.; Fathy, M.M. and Ramadan, A. (1994). Phytochemical and biological investigation of Jania rubens (L.) Lamx. Amino acids, proteins, nitrogenous bases and biological screening. J. Drug Res. Cairo, 21: $155-155$.

Tadros, M.M.; Ghaly, N.S. and Moharib, M.N. (2008). Molluscicidal and schistosomicidal activities of a steroidal saponin containing fraction from Dracaena fragrans (L.). J Egyp Soc Parasitol., 38: 585-598.

Van der Steen, W.J.; Van den Hoven, N.P. and Jager, J.C. (1968). A method for breeding and studying freshwater snails under continuous water change, with some remarks on growth and reproduction in Lymnaea stagnalis (L.). Neth $\mathbf{J}$ Zool., 19: 131-139.

WHO (World Health Organization) 1983 World Health Organization Report of the scientific working group on plant molluscicides. TDRrSCH-SWG 4Ž .r83.3, 1983:1.

WHO (World Health Organization) (2002). TDR strategic direction for research: schistosomiasis. In: World Health Organization, Genève.

Yacout, G.; Ghareeb, D. A.; Elguindy, N. M. and Elmoneam, A. A. A. (2011). Phytochemical constituents and bio screening activities of Alexandria Mediterranean Sea Green and Red Algae. J Enviro Sci Heal Part B, 38: 463478 . 